\title{
CHANGES IN POPULATIONS OF NESTING SEABIRDS ON THE BIRD ISLANDS, CAPE BRETON, NOVA SCOTIA
}

\author{
DAVID B. MCCORQUODALE ${ }^{*}$, DAN B. BANKS ${ }^{2}$, MATTHEW I. KERR $^{1}$, \\ RICHARD W. KNAPTON ${ }^{1}$, and DAVID L. HARRIS ${ }^{3}$ \\ ${ }^{1}$ Department of Behavioural and Life Sciences, \\ University College of Cape Breton, \\ Box 5300, Sydney, Nova Scotia B1P 6 L2 \\ ${ }^{2}$ Department of Natural Resources, \\ PO Box 610, Baddeck, Nova Scotia BOE 1BO \\ ${ }^{3}$ Department of Natural Resources \\ 300 Mountain Rd., Coxheath, Nova Scotia B1L 1A9
}

\begin{abstract}
The Bird Islands support the largest colonies of nesting seabirds in Nova Scotia. From a continental perspective the islands host one of the largest Great Cormorant (Phalacrocorax carbo) colonies in North America and a significant Razorbill (Alca torda) colony. However the islands are best known for nesting Atlantic Puffins (Fratercula arctica). Populations of all species have changed over the past 75 years, none so dramatically as Black-legged Kittiwakes (Rissa tridactyla). Kittiwakes colonized the islands 20 years ago and are now the most numerous nesting seabirds. Two other recent colonists, Herring (Larus argentatus) and Great Black-backed Gulls (L. marinus) are the next most common nesting species on the islands. In contrast the small colony of Common Murres (Uria aalge) and the large colonies of Arctic (Sterna paradisaea) and Common Terns (S. hirundo) of the 1920s have disappeared. Here we present recent estimates of breeding populations and summarize the data on changes in populations in the past 75 years based on a review of the literature, and surveys conducted from boats circumnavigating the islands during 11 different years from 1976 until 2000. The changes in breeding populations of seabirds on the Bird Islands show that their importance for conservation has changed through the years. For example in the 1920s about one third of all nesting Double-crested Cormorants in Nova Scotia were on the Bird Islands. In 1933 no Great Cormorants nested on the islands. In contrast in 2000 they supported the largest colony of Great Cormorants in North America and less than 1\% of the Double-crested Cormorants in eastern Canada.
\end{abstract}

En Nouvelle-Écosse, ce sont les îles Bird qui abritent les plus grosses colonies d'oiseaux de mer nicheurs. Les îles hébergent une des plus grosses colonies de Grands Cormorans (Phalacrocorax carbo) de l'Amérique du Nord et une colonie importante de Petits Pingouins (Alca torda). Cependant, les îles sont plus connues pour les Macareux moines (Fratercula arctica). Depuis les 75 dernières années, les populations de toutes les espèces ont changé, mais c'est la population de Mouettes tridactyles (Rissa tridactyla) qui a changé le plus. Il y a vingt ans, ces mouettes ont colonisé les îles et sont devenues les oiseaux de mer les plus abondants à s'y reproduire. Deux autres espèces ayant colonisé les îles depuis peu, le Goéland argenté (Larus argentatus) et le Goéland marin (L. marinus), arrivent au second rang pour ce qui est des oiseaux nicheurs les plus nombreux sur les îles. Par contre, la petite colonie de Guillemots marmettes (Uria aalge) et les grosses colonies de Sternes arctiques (Sterna paradisaea) et de Sternes pierregarins (S. hirundo) qui y vivaient durant les années 1920 ont disparu. Nous présentons ici des évaluations récentes des populations d'oiseaux nicheurs et les tendances démographiques depuis les 75 dernières années à partir d'une revue de la documentation, ainsi que les résultats de relevés effectués dans 11 années, entre 1976 et 2000, à bord de bateaux qui ont fait le tour des îles. Les changements dans les populations d'oiseaux de mer qui se reproduisent sur les îles Bird montrent que leur importance sur le plan de la conservation a varié au cours des années. Par exemple, dans les années 1920, environ un tiers de tous les Cormorans à aigrettes qui nichaient en Nouvelle-Écosse le faisaient sur les îles Bird. En 1933, aucun Grand Cormoran ne nichait sur les îles, tandis qu'en 2000, elles abritaient la plus grosse colonie de cette espèce en Amérique du Nord et moins de $1 \%$ des Cormorans à aigrettes de l'est du Canada.

*Author to whom correspondence should be addressed. 


\section{Introduction}

The Bird Islands support the largest and most significant seabird nesting colonies in Nova Scotia (Brown et al. 1975, Tufts 1986, Erskine 1992). Holland recognized the importance of the islands for nesting seabirds in 1766 (Harvey 1935). Unfortunately his writings do not document which species or how many were nesting. Bayley (1925) compiled the first reasonably complete survey of nesting seabirds. He visited the islands several times in the early 1920s and presented a summary of his sightings and counts. Since then some species have disappeared (e.g Arctic Tern), others have colonized the islands (e.g. Black-legged Kittiwake) and the populations of all have fluctuated.

The Important Bird Area (IBA) program aims to establish "a network of sites that conserve the natural diversity of Canadian bird species and are critical to the long-term viability of naturally occurring bird populations" (Dietz \& Chiasson 2000). Supporting a minimum of $1 \%$ of the continental population makes a site worthy of consideration by the IBA program. The combination of close to $10 \%$ of the continental population of Great Cormorants and the significant, on a provincial scale, populations of other nesting seabirds (e.g. Atlantic Puffin, Razorbill, Black-legged Kittiwake), made the Bird Islands an obvious choice for selection as one of the first IBA sites in Nova Scotia in 1999 (Dietz \& Chiasson 2000).

Besides Great Cormorants, other species that nest on the islands have been the cause for conservation concern historically. For example, fewer than 70 pairs of Double-crested Cormorants nested in Nova Scotia in the 1920s, including about 25 on the Bird Islands (Lewis 1928). Through the 1970s this species was the subject of concern because of low populations in eastern North America (Hatch 1995, Weseloh et al. 1995). However, in the past two decades concern has switched to the conflicts between people and rapidly expanding populations (Milton \& Austin-Smith 1983, Hatch 1995, Milton et al. 1995). Similarly, Razorbill populations in North America were severely reduced by egg harvesting and hunting in the 1800s (Nettleship \& Evans 1985). After a limited recovery, further declines were noted in the Gulf of St Lawrence between the 1960s and 1980s (Nettleship \& Evans 1985, Chapdelaine et al. 1999). More recently, there have been increases at several colonies in the Gulf of St. Lawrence (Chapdelaine et al. 1999).

Fluctuating populations, new immigrants and local extirpations change conservation priorities and suggest the value of monitoring nesting populations on the Bird Islands. Here we bring together published population estimates and counts of nesting seabirds on from the past 75 years. We also provide results from our surveys in the past 25 years. These data document local extirpations, colonization and population trends. We also compare population changes on the Bird Islands with patterns elsewhere in eastern Canada.

\section{Study Site}

The Islands The two Bird Islands are at the eastern edge of St. Anns Bay, offshore from Cape Dauphin, Cape Breton Island, Nova Scotia (46 $22^{\prime}$ North, 60' $23^{\prime}$ West). About $3 \mathrm{~km}$ from shore is Hertford Island (hereafter Hertford), the smaller of the two (15 ha, about $1.3 \mathrm{~km}$ by $125 \mathrm{~m}$ ). Less than a $\mathrm{km}$ to the east is Ciboux Island (hereafter Ciboux) ( $23 \mathrm{ha}$, about $1.6 \mathrm{~km}$ by $150 \mathrm{~m}$ ). The topography and vegetation of both islands are similar. The shoreline is either steep cliffs, up to $35 \mathrm{~m}$ high, or a jumble of boulders and rocks that have fallen from the cliffs. Cliffs are steepest on the northwest sides of both islands. This is a result of the tilt of the underlying coarse conglomerates and 
sandstones from the Carboniferous (Mississipian) (Roland 1982). The flat-tops are covered with grasses (e.g. Festuca rubra, Deschampsia flexuosa, and Poa pratensis) and prostrate shrubs (e.g. Empetrum nigrum, Potentilla tridentata and Juniperus communis) (Smith \& Schofield 1959). Holland claimed the islands were barren rock (Harvey 1935) which conflicts with both local oral history which suggests there were trees on the islands and Bayley's (1925) observation of stunted trees and standing dead trees. There are no trees on the islands now.

People resided at the lighthouse on Ciboux until 1952. Sheep grazing continued on the islands during the summer for many years after that. Ciboux was bought by the Nova Scotia Bird Society from Victoria County in 1958. Since 1994 it has been under the control of the Sanctuary and Scholarship Trust of that society. The province of Nova Scotia purchased Hertford in 1974 from the former lighthouse keeper, Daniel J. Campbell. For the past few decades only the occasional bird counter or boater has landed on the island. Tour boats have circumnavigated the islands daily in the summer for the past 30 years.

\section{Methods}

Estimates of populations of nesting seabirds Three methods were used to estimate populations. First, literature on seabirds on the Bird Islands was reviewed. Sources included private individuals with an interest in and knowledge of the islands (e.g. Bayley 1925), notes in regional works on birds (e.g. Lewis 1941, Tufts 1962, 1986, Erskine 1992) and censuses by the Canadian Wildlife Service (e.g. Lock \& Ross 1973, Erskine 1972, Brown et al. 1975, Lock et al. 1994). Some of these are reasonably complete censuses while others focus on only one or two species. Some sources conflict directly with others. We have included all the counts and estimates that we deem to be reliable, using consistency with other surveys of about the same vintage as a primary arbiter. An annotated list of all sources consulted is available from DBM.

The second method was a survey of seabirds conducted and organized by DBB and DLH, NSDNR. A preliminary cruise was done in 1976 and then 12 surveys from 1979 to 1997 . One morning in June or early July (range of dates 4 June to 8 July) four to eight people would embark in a small aluminum boat with outboard motor and circumnavigate the islands. During the trip individuals counted either nests or individuals of one or two species and all counts were recorded for each side of the two islands as the boat cruised slowly around the islands. Cormorant and kittiwake nests were relatively easy to count. The two species of cormorants were distinguished most years but for two years only cormorant spp. were counted. These have been assigned to species based on location of known colonies of the two species. Puffin and Razorbill nests are generally hidden from view. Most counts of these species are of adults standing in front of presumed nests, or adults entering or leaving nests. These counts are useful for monitoring population trends, but always underestimate total population. Black Guillemot nests are not visible and therefore all counts are of individuals. Counts were done before young were out of the nest, so counts are of adults only. Landings were made on the islands, especially Ciboux, in the late 1970s and 1988 to check for nesting Leach's Storm-petrels.

The third method involved 13 surveys from 27th May 2000 until 31st July 2000 by MIK, with assistance on some from RWK and DBM. Twelve were conducted from the deck of a tour boat operated by Captain Vincent Van Schaik of Bird Island Tours. Both nests and individuals were counted for cormorants, kittiwakes, puffins and Razorbills. Only individual guillemots were counted. Cormorant and kittiwake colonies were photographed from the boat and during a helicopter flight over the islands 31 July 2000. 
Counts of nests from the photographs were co-ordinated with counts from the boat. On 31 st July 2000 a ground check of Ciboux for nesting storm-petrels was also completed. Totals for each species for 2000 are reported as the highest count obtained during one day.

\section{Species Accounts, Population Estimates and Trends}

Great Cormorant (Phalacrocorax carbo) About 500 pairs of Great Cormorants nested on the islands from the early 1980s until 2000 (Table 1). There is a slight peak, approaching 600 nests, from the early 1980s until the mid-1990s. This contrasts with only 100 nests in 1925 and even lower numbers, fewer than 50 and even none in some years, through the 1930s and 1940s. Significant population growth appears to have occurred through the 1960s as shown by Neilly's count of 700 individuals in 1968 (Erskine 1972).

Table 1 Estimates of the numbers of Great Cormorant, Double-crested Cormorant and Blacklegged Kittiwake during the breeding season on the Bird Islands, Nova Scotia, 1925 to 2000. The number is the number of nests, except those in parentheses which are number of individuals. No entry indicates the species was not mentioned or counted that year. A zero indicates a specific acknowledgement that the species did not nest or was not present.

\begin{tabular}{|c|c|c|c|c|}
\hline Year & $\begin{array}{l}\text { Great } \\
\text { Cormorant }\end{array}$ & $\begin{array}{l}\text { Double-crested } \\
\text { Cormorant }\end{array}$ & $\begin{array}{l}\text { Black-legged } \\
\text { Kittiwake }\end{array}$ & Source \\
\hline 1925 & 100 & 25 & 0 & Bayley 1925 \\
\hline 1929 & 75 & & & Erskine 1972 \\
\hline 1933 & 0 & & & Tufts 1962 \\
\hline 1935 & $50+$ & & & Erskine 1972 \\
\hline 1940 & 39 & & & Tufts 1962 \\
\hline 1962 & & some & & Tufts 1986 \\
\hline 1963 & (200) & 0 & & Erskine 1972 \\
\hline 1965 & $(200+)$ & 0 & & Erskine 1972 \\
\hline 1968 & (700) & 0 & & Erskine 1972 \\
\hline 1971 & 398 & 0 & & Lock \& Ross 1973 \\
\hline 1976 & & & 0 & this study \\
\hline 1979 & $(675)$ & & 0 & this study \\
\hline 1980 & $(756)$ & & 126 & this study \\
\hline 1981 & (1197) & (258) & & this study* \\
\hline 1982 & 572 & $(110)$ & 268 & this study \\
\hline 1983 & 537 & 230 & 232 & $\begin{array}{l}\text { NS Colonial Seabird } \\
\text { Database }\end{array}$ \\
\hline 1984 & (776) & (156) & 228 & this study \\
\hline 1985 & & & 208 & MacDonald 1985 \\
\hline 1988 & $(541)$ & (186) & 282 & this study \\
\hline 1989 & & & 375 & this study \\
\hline 1990 & & & 773 & this study \\
\hline 1991 & 543 & 219 & 623 & this study \\
\hline 1993 & 537 & 224 & 1456 & this study* \\
\hline 1995 & 614 & 328 & 666 & this study \\
\hline 1997 & 415 & 285 & 1139 & this study \\
\hline 2000 & 410 & 245 & 1269 & this study \\
\hline
\end{tabular}

* Cormorants were counted as cormorant sp. and assigned to species by location of known colonies. 
Historically, the Bird Islands have been an important refuge in times of low populations and consistently one of the major colonies in North America. Population change has mirrored growth throughout Atlantic Canada and Saint Pierre et Miquelon. Early in the 20th century Bent (1922) suggested the Great Cormorant had been extirpated from North America. Although he was undoubtedly wrong, his assertion demonstrates their rarity in North America. In 1925 the Bird Islands supported the largest colony of Great Cormorants in North America, probably more than 75\% of the total population (Bayley 1925, Erskine 1972). Small numbers were known from only two other locations, the North Shore of the St. Lawrence and the Magdalen Islands, Quebec (Erskine 1972). In 1940 Lewis (1941) undertook a complete survey of colonies in Canada. The 39 pairs on the Bird Islands represented 3.6\% of the North American population at that time, the majority nesting on Anticosti Island and the North Shore of the St. Lawrence in Quebec. The next reasonably complete count for Canada is from the early 1970s (Lock \& Ross 1973, Brown et al. 1975). The 398 nests on the Bird Islands then represented close to $15 \%$ of the total for North America. Since then, numbers on Bird Islands have been relatively stable, while the North American population has increased. Now the colonies on the Bird Islands probably represent no more than $8 \%$ of the North American population of about 5,000 pairs (Erskine 1992, Fradette 1992, Lock et al. 1994).

Double-crested Cormorant (Phalacrocoraxauritus) From the early 1990s until 2000 more than 200 pairs of Double-crested Cormorants nested on the Bird Islands (Table 1), with a peak of more than 300 pairs in 1995. The largest colonies are on Ciboux and have been since they recolonized the islands in the 1970s. In the 1920s about 25 pairs nested (Bayley 1925) and Tufts (1962) reported their presence in 1940. In the 1960s and early 1970s this species was largely absent from the islands, although Tufts (1986) did find some in 1962. Since then there has been a dramatic increase, although there is some evidence of a small decrease in recent years. It is likely that estimates from the 1980s and early 1990s are low because two colonies are not visible from a boat and therefore missed by the NSDNR surveys that did not land on Ciboux.

The pattern of population change on the Bird Islands fits the general pattern observed in eastern North America over the past 75 years. Populations were low prior to 1950 and through the 1970s they appeared on lists of species of concern (Hatch 1995). Since the late 1970s there has been a dramatic increase (Chapdelaine \& Bedard 1995, Hatch 1995). One exception is the complete lack of birds in the 1960 s and early 1970 s on the Bird Islands. Several surveys in the 1960s and 1970s explicitly state no nests of this species were present (Erskine 1972, Brown et al. 1975).

In the 1920s one of only two colonies of Double-crested Cormorants in Nova Scotia was on the Bird Islands (Lewis 1928), obviously an important refuge for a distinctly rare species in the province at that time. Since then the relative importance of the Bird Islands in the province has declined, even though the number of nests has increased. This is largely because of the burgeoning Nova Scotia population, more than 15,000 in the 1990s (Erskine 1992, Milton et al. 1995).

Several mixed colonies, of Great and Double-crested Cormorants, occur in Prince Edward Island and Nova Scotia (Lock \& Ross 1973, Godfrey 1986, Milton \& Austin-Smith 1983). Although the Bird Islands as a whole are a mixed colony, each sub-colony was usually either one species or the other. Since there are no trees on the islands, all nests of Double-crested Cormorants were on the ground. Ross (1974-76) found that although Double-crested Cormorants prefer to nest in trees, they use a range of nesting locations.

Leach's Storm-petrel (Oceanodroma leucorhoa) No burrows or odours of nesting petrels were found during a visit to Ciboux in July 2000. In the late 1970s and again 
in 1988 a few $(<5)$ nests were found on Ciboux, mostly around old foundations of buildings. Bayley (1925) reported many petrels nesting on the Bird Islands in the early 1920s. These hole-nesting nocturnal seabirds are not easily counted. Therefore only anecdotal observations are available for the islands. They prefer to burrow amongst tree roots. As there are no trees on the islands now, nesting habitat is limited.

Herring Gull (Larus argentatus) More than 400 adult Herring Gulls were counted on the islands in June 2000. This is down from the peak counts of about 600 nests in 1971, several hundred nests in 1979 and more than 1,000 individuals in 1985. Gulls were not the focus of the NSDNR surveys and therefore the data are limited. Herring Gulls have nested on the islands since at least 1954 when Smith \& Schofield (1959) estimated at least 300 young on Hertford alone. There are no nesting records prior to 1954 and Bayley (1925) explicitly stated they were casual summer visitors and did not nest.

Population trends on the islands are similar to trends for Nova Scotia and for northeastern North America. Populations were low in the early 1900s and then a tremendous population explosion (Lock 1989, Erskine 1992). In the past 10 to 15 years numbers have started to stabilize or decline. In Cape Breton this recent population decline is probably due to closure of fish plants and declining use of open landfills in the 1990s.

Great Black-backed Gull (Larus marinus) In 2000, 641 adult Great Black-backed Gulls were counted on the islands. Data for the 1980s and 1990s are lacking. Two counts, a conservative estimate of more than 600 pairs in 1979 and 750 pairs in 1971 (Brown et al. 1975), suggest a higher population through the 1970s. No other estimates are available. The 1971 count represents the first report of nesting on the islands. Godfrey (1958) considered them a common nesting species on Cape Breton Island suggesting they have nested on the Bird Islands since at least the 1950s. However he appears not to have visited the Bird Islands.

Like those of Herring Gulls, Great Black-backed Gull populations have increased dramatically in Nova Scotia and in northeastern North America through most of the 1900s (Erskine 1992). Increases in nesting on the Bird Islands have been part of this larger picture.

Black-legged Kittiwake (Rissa tridactyla) Kittiwakes were the most numerous nesting seabird on the islands in 2000, with more than 1400 nests (Table 1). The islands were first colonized in 1980 when more than 120 pairs nested. Adults were around the islands the year before but did not nest. Through the 1980s, 200-300 pairs nested each year. Then in the late 1980s the population increased again. From 1990 until 2000, there was an average of almost 1000 nests on six surveys.

The colonization and population increase on the islands is part of a general trend in Nova Scotia (Lock 1987, Erskine 1992) and the southern edge of this species range in eastern Canada (Chapdelaine \& Brousseau 1989, Fradette 1992). The first nests for the province were found on the east coast of Cape Breton in 1971 and since then they have colonized seaside cliffs elsewhere in eastern Cape Breton.

Arctic Tern (Sterna paradisaea) and Common Tern (Sterna hirundo) Both Arctic and Common Terns, nested in the hundreds on the small rocks between the two islands in the 1920s (Bayley 1925). Since then there are no reports of nests. In the summer individuals fish around the islands.

Both species commonly nest around Cape Breton Island. Tern populations have declined during the past 100 years in Nova Scotia and the presence of gulls at nesting colonies is thought to be a major factor in the decline (Lock 1989, Erskine 1992). Tern colonies are ephemeral along the coast of Cape Breton. Often terns will use a location 
for a few years and then move to another. Because of their mobility, a broad survey of the Cape Breton coast is the only effective way to monitor population trends (Lock 1989).

Atlantic Puffin (Fratercula arctica) The more than 750 adults and 200 presumed nests in 2000 are the highest population estimates since the early 1960s (Table 2). Tufts noted that his count of more than 800 individuals in 1964 was less than his estimate from 1933. Bayley (1925) thought there were more than 1000 adults in the 1920s. In contrast, estimates from seabird surveys in the early 1970s and our surveys through the 1980s and early 1990s suggested only about 100 nesting pairs, with lows of less than 50. Because of the difficulty in detecting nests, our surveys were intended to be an index of the number of puffins, rather than a complete count. Considering the counts of presumed nests from 1980 until 1993, there is a strong indication of an increase. However in 1997 the number of presumed nests was extremely low again. The count of 208 in 2000 suggests this was a temporary dip. Like kittiwakes and other seabirds, puffins often abandon nests in years of low food supply, possibly accounting for the low count in 1997.

Table 2 Estimates of the numbers of Atlantic Puffin, Razorbill and Black Guillemot during the breeding season on the Bird Islands, Nova Scotia, 1925 to 2000. The number is an estimate of the number of nests, except those in parentheses which are for individuals. No entry indicates the species was not mentioned or counted that year. A zero indicates a specific acknowledgement that the species did not nest or was not present.

\begin{tabular}{|c|c|c|c|c|}
\hline Year & $\begin{array}{l}\text { Atlantic } \\
\text { Puffin }\end{array}$ & Razorbill & $\begin{array}{l}\text { Black } \\
\text { Guillemot }\end{array}$ & Source \\
\hline 1925 & (1000) & $(600)$ & $(400)$ & Bayley 1925 \\
\hline 1933 & (100s) & & & Tufts 1962 \\
\hline 1940 & & & $(40)$ & Tufts 1962 \\
\hline 1964 & $800+$ & $(200-300)$ & & Tufts 1986 \\
\hline 1971 & $(100-140)$ & & & Brown et al. 1975 \\
\hline 1976 & (90) & (77) & & this study \\
\hline 1979 & (88) & (69) & (158) & this study \\
\hline 1980 & 20 & 69 & $(151)$ & this study \\
\hline 1981 & (171) & (101) & (76) & this study \\
\hline 1982 & 35 & 56 & (65) & this study \\
\hline 1984 & 57 & 61 & (102) & this study \\
\hline 1985 & (160) & 45 & & MacDonald 1985 \\
\hline 1988 & 39 & 104 & (149) & this study \\
\hline 1989 & 47 & 83 & (364) & this study \\
\hline 1990 & 99 & 131 & (345) & this study \\
\hline 1991 & 63 & 82 & (107) & this study \\
\hline 1993 & 107 & 186 & (336) & this study \\
\hline 1995 & 87 & 139 & (330) & this study \\
\hline 1997 & 29 & 215 & (346) & this study \\
\hline 2000 & $\begin{array}{l}208 \\
(760)\end{array}$ & $\begin{array}{l}180 \\
(591)\end{array}$ & $(613)$ & this study \\
\hline
\end{tabular}

The trends in puffin populations seen on the Bird Islands were lows in the early 1900s, peaks in the 1920s and 30s, declines especially in the 1970s and then recent increases to close to historical maxima. Similar trends have been documented elsewhere in eastern Canada (Nettleship \& Evans 1985, Blanchard 1994, Chapdelaine 
1995, Chardine 1999b). The Bird Islands host a small, peripheral puffin population. Only a few hundred pairs nest, compared to an eastern North American population of close to 400,000 pairs (Nettleship \& Evans 1985, Chardine 1999). Yet this small population shows trends similar to the much larger whole. It may be possible to effectively monitor the large, by focusing on the small.

Common Murre (Uria aalge) Murres were not found in 2000, nor have any been seen on the islands since the 1960s. Bayley (1925) reported 12 pairs in the early 1920s, Taverner found a pair in 1929 (Godfrey 1958) and Tufts found one in 1965 (Tufts 1986). Common Murre populations in the Gulf of St. Lawrence and elsewhere in eastern Canada are doing reasonably well in the past 20 years (Nettleship \& Evans 1985, Chardine 1999a) and a few hundred pairs nest as close as the Magdalen Islands (Fradette 1992). Populations were, however, drastically reduced through hunting and harvesting eggs in most colonies in the 1800s (Nettleship \& Evans 1985). The Bird Islands are at the southern limit of the range of Common Murres and this is probably part of the reason why this colony has been extirpated, while elsewhere in eastern North America populations have rebounded from low levels in the mid-1900s.

Razorbill (Alca torda) Counts of close to 600 adult Razorbills and 180 presumed nests in 2000 were similar to counts from the 1920s (Bayley 1925) and through most of the 1990s (Table 5). The last four surveys and Bayley's are the five highest totals. In the intervening period both Tufts and our surveys suggest that numbers were lower.

Razorbill population declines were widespread and serious in eastern Canada up until the early 1980s (Nettleship \& Evans 1985). Certainly hunting and egg harvesting were major contributing factors historically. However significant decreases continued into the early 1980s. The colonies on the Magdalen Islands were important as a refuge in times of extremely low populations in the early 1900s. They declined by about $85 \%$ between 1960 and 1982. Since that time populations have increased at five of seven major colonies in eastern Canada (Chapdelaine et al. 1999). A similar pattern has been found in some smaller colonies in the Gulf of St Lawrence and Bay of Fundy (Chapdelaine et al. 1999). Certainly there is evidence for recent increases in numbers at the Bird Islands. It is unclear how the present population, or that of the 1920s, compares with numbers that used the islands 200 years ago.

The Razorbills nesting on the Bird Islands represent about $2 \%$ of the North American population of 15,000 to 20,000 (Nettleship \& Evans 1985, Lock et al. 1994, Chapdelaine et al. 1999). There are relatively few Razorbill colonies in eastern North America because more than two-thirds of the population nests at the Gannet Clusters in Labrador (Nettleship \& Evans 1985). Several hundred pairs nest on the Magdalen Islands (Fradette 1992). The combination of few colonies and consistent declines long after protection from hunting and egg collecting make monitoring efforts important for this species.

Black Guillemot (Cephus grille) Morethan 600 adult Black Guillemots were counted in 2000, the highest recorded for the Bird Islands (Table 6). After a dip in numbers from the late 1970s into the early 1980s, there was a consistent increase through the 1980s. Except for one low count in 1991, numbers remained high through the 1990s, just slightly lower than Bayley's (1925) count from the 1920s. The lowest estimate is Tufts (1962) from a visit to the islands in 1940.

It is difficult to estimate numbers of Black Guillemots because they do not nest in large, discrete colonies, and nests are under a jumble of rocks and thus invisible to people (Nettleship \& Evans 1985). In contrast to other alcids in eastern Canada, the data on population trends and size are therefore limited. The overall North American population is estimated to be 50,000 to 100, 000 pairs (Nettleship \& Evans 1984). On the North Shore of the St. Lawrence populations increased following legislative 
protection in the 1920s and then declined after 1965 (Chapdelaine \& Brousseau 1984). In the Gulf of Maine numbers increased from 1931 until 1970 and remained stable into the 1980s (Nettleship \& Evans 1984).

\section{Discussion}

Changes in nesting species Four species that nested on the islands early in the 1900 s do so no longer. Two were very numerous, Arctic and Common Terns, a third, Common Murre, was not numerous and the status of the fourth, Leach's Storm-petrel, is unclear. Other species have colonized the islands during this time. Herring Gulls first nested sometime prior to 1954 and Great Black-backed Gulls probably first nested there in the 1950s or early 1960s. The now large colony of Black-legged Kittiwakes was established in 1980. These three recent colonists are now the three most abundant breeding species on the islands. Conversely, in the 1920s the terns vied with Atlantic Puffins as the most abundant seabirds on the islands.

Disturbance Sea bird colonies are concentrated in space and time, therefore populations are vulnerable to local disturbance as well as broader scale disturbances. Boat traffic, changes in fish stocks and oil are thought to be the disturbances most likely to be detrimental to nesting birds on the Bird Islands.

Lobster boats and tour boats have circumnavigated the islands for decades. These boats appear to have little effect on the birds. Most birds do not react to passing boats. A passing Bald Eagle (Haliaeetus leucocephalus) attracts far more attention than a lobster boat or a tour boat. Of greater concern are smaller craft (e.g. kayaks) which appear to be noticed and reacted to more frequently than larger boats. However no work has quantified these impressions. We do know that landing on the island when the birds are nesting causes adults to leave nests and if done frequently for extended periods could cause problems. Therefore an enforceable ban on landing on the islands is critical to conservation of the seabird colonies.

Undoubtedly changes in nesting populations both on Bird Islands and elsewhere are at least partially linked with changes in populations of the food supply. The congruence of trends on the Bird Islands for cormorants, Razorbills and kittiwakes elsewhere in the Gulf of St. Lawrence and eastern Canada emphasize the connections. Recent increases in alcid populations have been linked to closures of the groundfishery. With fewer groundfish, more fish may be available for alcids such as puffins (Chardine 1999). Little work has been done, however, to document these interactions between trophic levels. Fishing has co-existed with the nesting colonies for at least 200 years. Recently, the lobster fishery has been intense. We have no evidence of direct links between fishing and bird populations.

A variety of large commercial boats sail the waters in the vicinity of the Bird Islands. With commercial traffic comes the risk of oil spills, large ones from tankers and numerous smaller ones from all vessels. Cargo ships entering the Bras d'Or Lakes pass within a few $\mathrm{km}$ of the islands. Many large cargo ships and some oil tankers pass through Sydney Bight to use the port of Sydney, about $30 \mathrm{~km}$ from the islands. A major shipping lane connecting the St. Lawrence Seaway and the Atlantic passes through the Cabot Strait, about $70 \mathrm{~km}$ to the north. This traffic will result in some oils spills and potential problems for nesting birds. Surveys of beached birds in southern Newfoundland have shown an increase in oiled birds since 1984 (Wiese \& Ryan 1999). With the recent interest in exploring for oil and gas offshore of Cape Breton there is a potential for a more serious problem. 
Protected Status The owners of the two islands, the Nova Scotia Bird Society and the Province of Nova Scotia, through the Department of Natural Resources, both understand the conservation significance of the islands. Similarly the tour boat operators and the fishers who ply the waters around the islands understand their significance. There is an implicit understanding that the area is protected and that human disturbance, especially during the nesting season, be avoided. Despite this implicit protection, which has worked well for the past 30 years, there is no legal protected status for the islands. It has worked partly because of the interest and efforts of fishers and tour operators to protect what they realize is an important natural resource. NSDNR staff have proposed and written the required justifications, that the islands be declared a Wildlife Management Area. This status would enshrine regulations governing human disturbance on the islands and to codify that landing on the islands be prohibited during the nesting season. A cooperative venture between the two owners could make this happen. Long term effective protection will depend to a large extent on the cooperation and attitudes of the fishers and tour operators who ply the waters daily through the nesting season. The IBA program has worked to promote these goals by encouraging dialogue between the Nova Scotia Bird Society and NSDNR about the Wildlife Management Area proposal, meeting with fishers who use the area, and producing a conservation plan for the islands.

The current large populations of Great Cormorants and Razorbill make this a site of regional conservation importance. Given the change in species composition and populations during the past 75 years, it can be assumed more changes will take place in the future. The significance of the arrival of gulls and the importance of distinguishing which species of cormorants were nesting was not immediately recognized. Ongoing monitoring should attempt to include all species, including new colonists.

\section{Acknowledgements}

We appreciate the assistance of the numerous people who assisted with the NSDNR surveys over the past 25 years. Vince Van Schaik and Bird Island Tours provided valuable assistance during the summer of 2000. Roland Chiasson and Sabine Dietz facilitated work on the Bird Islands IBA project. We thank the Canadian Nature Federation, BirdLife International, Canada Millenium Partnership Program and Bird Studies Canada for financial support through the IBA program and UCCB for support through internal research grants to DBM and RWK and two anonymous reviewers for helpful comments.

\section{References}

Bayley IA (1925) The birds of the Bird Islands, Nova Scotia. Can Field-Nat 29:183-187 Bent AC (1922) Life histories of North American Petrels, Pelicans and their allies. US Natl Mus Bull 121

Blanchard KA (1994) Culture and seabird conservation: the North Shore of the Gulf of St. Lawrence, Canada. In: Nettleship DN, Burger J, Gochfield M (eds) Seabirds on islands: threats, case studies and action plans. Birdlife Conservation Series 1, Birdlife International, Cambridge, p 186-209

Brown RGB, Nettleship DN, Germain P, Tull CE, Davis T (1975) Atlas of eastern Canadian seabirds. Canadian Wildlife Service, Environment Canada, Ottawa

Chapdelaine G (1995) Fourteenth census of seabird populations in the sanctuaries of the North Shore of the Gulf of St. Lawrence, 1993. Can Field-Nat 109:220-226 
Chapdelaine G, Bedard J (1995) Recent changes in the abundance and distribution of the Double-crested Cormorant in the St. Lawrence River, estuary and Gulf, Quebec, 1978-1990. Colon Waterbirds 18 (Spec Publ 1):70-77

Chapdelaine G, Brousseau P (1984) Douzieme inventaire de populations d'oiseaux marins dans les refuges de la Cote-Nord du golfe Saint-Laurent. Can Field-Nat 98:178-183

Chapdelaine G, Brousseau P (1989) Size and trends of Black-legged Kittiwake (Rissa tridactyla) populations in the Gulf of St. Lawrence (Quebec) 1974-1985. Am Birds 43:21-24

Chapdelaine G, Diamond AW, Elliot RD, Robertson GJ (1999) Population status and current trends of Razorbills in Canada. Bird Trends 7:18-22

Chardine JW (1999a) Overview of seabird status and conservation in Canada. Bird Trends 7:1-7

Chardine JW (1999b) Population status and trends of the Atlantic Puffin in North America. Bird Trends 7:15-17

Dietz S, Chiasson R (2000) Bird Islands important bird area: conservation concerns and measures. Canadian Nature Federation, Ottawa and Bird Studies Canada, Port Rowan, ON

Erskine AJ (1972) The Great Cormorants of eastern Canada. Canadian Wildlife Service Occasional Paper 14

Erskine AJ (1992) Atlas of breeding birds of the Maritime Provinces. Nimbus Publishing and Nova Scotia Museum, Halifax

Fradette P (1992) Les Oiseaux des Iles-de-la-Madeleine: populations et sites d'observation. Attention Frag'iles, Iles-de-la-Madeleine, Quebec

Godfrey WE (1958) Birds of Cape Breton Island. Can Field-Nat 72:7-27

Godfrey WE (1986) The birds of Canada, rev edn. National Museum of Natural Science, Ottawa

Harvey DC (1935) Holland's description of Cape Breton Island and other documents. Public Archives of Nova Scotia Publication 2

Hatch JJ (1995) Changing populations of Double-crested Cormorants. Colon Waterbirds 18 (Spec Publ 1):8-24

Lewis HF (1928) The natural history of the Double-crested Cormorant (Phalocrocorax auritus auritus (Lesson)). Ru-Mi-Lou Books, Ottawa

Lewis HF (1941) Breeding European Cormorants of North America. Auk 58:360-363

LockAR (1987) Recent increases in the breeding population of Black-legged Kittiwakes, Rissa tridactyla, in Nova Scotia. Can Field-Nat 101:331-334

Lock AR (1989) A brief history of terns in Nova Scotia. NS Birds 31:59-61

LockAR, Brown RGB, Gerriets SH (1994) Gazetteer of marine birds in Atlantic Canada. Canadian Wildlife Service, Environment Canada, Ottawa

Lock AR, Ross RK (1973) The nesting of the Great Cormorant (Phalacrocorax carbo) and the Double-crested Cormorant (Phalacrocorax auritus) in Nova Scotia in 1971. Can Field-Nat 87:43-49

MacDonald C (1985) (New Waterford, NS). Personal communication

Milton GR, Austin-Smith PJ (1983) Changes in the abundance and distribution of Double-crested Cormorants (Phalacrocorax auritus) and the Great Cormorants (Phalacrocorax carbo) in Nova Scotia. Colon Waterbirds 6:130-138

Milton GR, Austin-Smith PJ, Farmer GJ (1995) Shouting at shags: a case study of cormorant management in Nova Scotia. Colon Waterbirds 18 (Spec Publ 1):91-98

Nettleship DN, Evans PGH (1985) Distribution and status of the Atlantic Alcidae. In: Nettleship DN, Birkhead TR (eds) The Atlantic Alcidae. Academic Press, London, p 53-154 
Roland AE (1982) Geological background and physiography of Nova Scotia. Nova Scotian Institute of Science and Nova Scotia Museum, Halifax

Ross RK (1974-76) A comparison of the feeding requirements of the Great Cormorant (Phalacrocorax carbo L.) and Double-crested Cormorants (P. auritus Lesson) in Nova Scotia. Proc NS Inst Sci 27:114-132

Smith EC, Schofield WB (1959) Contributions to the flora of Nova Scotia VI: notes on the vegetation of the Bird Islands. Can Field-Nat 73:155-160

Tufts RW (1962) The birds of Nova Scotia. Nova Scotia Museum, Halifax

Tufts RW (1986) Birds of Nova Scotia, $3^{\text {rd }}$ edn. Nimbus Publishing and Nova Scotia Museum, Halifax

Weseloh DV, Ewins PJ, Struger J, Mineau P, Bishop CA, Postupalsky S, Ludwig JP (1995) Double-crested Cormorants of the Great Lakes: changes in population size, breeding distribution and reproductive output between 1913 and 1991. Colon Waterbirds 18 (Spec Publ 1):48-59

Wiese FK, Ryan PC (1999) Trends of chronic oil pollution in southeast Newfoundland assessed through beached-bird surveys 1984-1997. Bird Trends 7:36-40 